\title{
THE ETHANOLIC STEM EXTRACT OF CARYOPTERIS $X$ CLANDONENSIS POSSESES ANTIPROLIFERATIVE POTENTIAL BY BLOCKING BREAST CANCER CELLS IN MITOSIS
}

\author{
OANA SICORA*, MARA ANA NAGHI, IOSIF SOOS, COSMIN SICORA \\ Biological Research Center Jibou, 16 Wesselenyi Street, 455200, Jibou, Sălaj County, Romania \\ *corresponding author: oanasavuro@yahoo.com
}

Manuscript received: July 2017

\begin{abstract}
In the present study it was evaluated the antiproliferative activity of Caryopteris $x$ clandonensis ethanolic stem extract on MCF-7 breast cancer cells. To characterize the effects of the extract on the treated cells the MTT cytotoxicity assay, DAPI staining and agarose gel electrophoresis, were performed. The cytotoxicity of the ethanolic extract of Caryopteris $x$ clandonensis is concentration-dependent and the breast cancer cells treated with this extract are highly affected showing a modified nucleus, an increased mitotic index and subsequently, cell destruction. These findings demonstrate the ethanolic extract has antiproliferative effect on breast cancer cells.
\end{abstract}

\section{Rezumat}

Studiul prezent evaluează acțiunea antiproliferantă a extractului etanolic al tulpinilor de Caryopteris $x$ calndonensis asupra celulelor MCF-7 de cancer mamar. Efectul extractului asupra celulelor tratate s-a evaluat prin testele MTT, colorare cu DAPI şi electroforeză ADN. Efectul citotoxic al extractului etanolic de Caryopteris x clandonensis este dependent de concentrație. Celulele tumorale tratate cu acest extract au modificări la nivelul nucleului, index mitotic crescut și ulterior suferă distrugere celulară. Rezultatele demonstrează efectul antiproliferant al extractului etanolic testat asupra celulelor tumorale mamare.

Keywords: Caryopteris $x$ clandonensis, breast cancer cells, antiproliferative effect

\section{Introduction}

Cancer is the second leading cause of death worldwide after cardiovascular acute diseases [1]. It is characterized by abnormal proliferation of cells that are able to escape various mechanisms of elimination [2]. One of the hallmarks of cancer diseases is evasion from apoptosis or programmed cell death. During mitotic division cells progress through mitosis and are able to pass all the mitotic checkpoints. When a defect arises, the spindle assembly checkpoint is activated and makes the cell to arrest in mitosis and subsequently to die [3].

Modern medicine and traditional medicine treat cancer by using substances from chemical synthesis or herbal origin that is able to interfere with cancer cell division and/or to induce apoptosis of cancerous cells.

Plants are a rich source of bioactive compounds and researchers all over the world work in screening plant compounds that are more efficient against cancer cell proliferation.

In this study we investigated the antiproliferative activity of Caryopteris $x$ clandonensis ethanolic extract on MCF-7 cells.

Caryopteris $x$ clandonensis $(C x c)$ is part of Lamiaceae family and is a hybrid plant obtained from Caryopteris incana and Caryopteris mongolica in 1930 [4]. It is a plant spread especially in Asia (China, Korea, Japan, Mongolia) [5] but in the last century it gathered an ornamental value being popular in botanical gardens, landscaping and in apiculture because it attracts insects [6]. From root bark of $C x c$ have been isolated quinones that possess moluscidal activity and radical scavenging activity [7] and from the stem part of the plants harpagide type iridoides have been isolated [8]. There are no records for $C x c$ uses as a medicinal plant. However, in Asia the aerial parts of C. mongolica, a parent of the Cxc hybrid, are used in traditional medicine against cough, cold, aches, oedema and rheumatism [9-11]. Recently, from the roots of this plant have been isolated ortoquinone that has an antibacterial effect [12] and from the aerial parts and roots of the plant were isolated diterpenoids that have cholinesterase-inhibitory effect $[9,13]$. The other parent of the hybrid, $C$. incana, in Chinese traditional medicine has the same use as $C$. mongolica [14, 15]. The plant contains steroids, glycosides, iridoide, flavonoids and stigmasterols. For some of these components it is recorded the radical scavenging activity [16], antioxidant activity [17], antibacterial [18] and antiangiogenic activities 
[19] and cytoprotective effect [15]. Recently, the cytotoxic effect of isolated abietane diterpenoides was demonstrated on A549 that is a human lung adenocarcinoma cell line and on Hey cells, a human ovarian carcinoma cell line [20].

\section{Materials and Methods}

Collection of plant material. The aerial parts of Cxc were collected from Sălaj County, Romania and a voucher specimen was deposited at the Biological Research Centre Jibou Herbarium (number 2/2015). Leaves and flowers were separated from the stems and all separated plant parts were dried for $16 \mathrm{~h}$ in the drying chamber with forced air convection (Binder model ED-720) at $50^{\circ} \mathrm{C}$. The dried plant material was cut in small pieces and subjected to extraction. Extraction of plant material. The small cut pieces of dried stems, flowers and leaves of Cxc (40 g) were extracted in $400 \mathrm{~mL}$ ethanol for $60 \mathrm{~h}$, at room temperature on a magnetic stirrer. The extracts were filtered using qualitative filter paper (Filters Fioroni, France) and then the solvent was eliminated under reduced pressure in a rotaevaporator (Heidolph, model Hei-VAP Advantage). The dried material was weighted and dissolved in DMSO and the final concentrations of the extracts were calculated.

TLC fingerprinting profile of Cxc. Thin layer chromatographic (TLC) profile of ethanolic, extracts of stem, flowers and leaves of $C x c$ dissolved in DMSO was performed on aluminium backed TLC plates (Merck, silica gel $60 \mathrm{~F}_{254}$ ). TLC plates were developed in a saturated chamber using three mobile phases of different polarity - nonpolar/basic, intermediate polarity/acidic and polar/neutral. TLC plates were sprayed with vanillin-sulphuric acid mixture and colour development was achieved by heating the TLC plates at $110^{\circ} \mathrm{C}$ in a dry heater. Qualitative detection of phenolic compounds by TLC. TLC plates were prepared and processed as described in the method for TLC fingerprinting profile. The plates were developed by spraying with $\mathrm{FeCl}_{3}$. The presence of phenolic compounds was determined by the appearance of grey and black bands.

Cell culture. The MCF-7 breast cancer cell line was a kind gift from Dr. Lajos Matej from BRC, Szeged, Hungary. The cell line was cultivated in DMEM medium supplemented with $10 \%$ FBS and $100 \mathrm{U} / \mathrm{mL}$ penicillin, $100 \mu \mathrm{g} / \mathrm{mL}$ streptomycin in an incubator at $37^{\circ} \mathrm{C}, 5 \% \mathrm{CO}_{2}$ in a humidified atmosphere.

MTT cytotoxicity test. The test is based on the capacity of living cells to reduce the MTT (3-(4,5-dimethylthiazol-2-yl)-2-5-diphenyl tetrazolium bromide) to a purple formazan product. Cells were plated in 96 wells cell culture plates $\left(9 \times 10^{3} /\right.$ well $)$. Cells were grown for $24 \mathrm{~h}$ in the incubator at $37^{\circ} \mathrm{C}$ and then treated for $24 \mathrm{~h}$ or $48 \mathrm{~h}$ with different concentrations of $C x c$ ethanolic stem extract. After $24 \mathrm{~h}$ or $48 \mathrm{~h}, 20 \mu \mathrm{L}$ of MTT solution was added on the cells and incubated at $37^{\circ} \mathrm{C}$ for $3 \mathrm{~h}$. Then $150 \mu \mathrm{L}$ of MTT solvent was added on the cells to dissolve the formazan crystals. The cells were incubated in the dark for 50 min on an orbital shaker and then the absorbances were measured using an ELISA reader (PR2100, BioRad) at $550 \mathrm{~nm}$ wavelength with a reference wavelength at $750 \mathrm{~nm}$. The negative control was represented by sets of untreated cells (NT). The positive control was a set of cells treated with cisplatin, a chemotherapeutic agent known to induce cytotoxicity. Both, negative and positive controls were run under the same conditions as extract treated cells. All experiments were performed in triplicate with concentrations of $C x c$ extract ranging from 0.02 to $5 \mathrm{mg} / \mathrm{mL}$ and the data are represented as mean \pm standard deviation of the readings of each group. The cell viability percentage was calculated as follows:

$\%$ cell viability $=($ absorbances of treated cells $)$ absorbances of negative controls) $x 100$.

DAPI staining and Mitotic Index. MCF-7 cells were grown on coverslips in 6 well plates till they reach a $75 \%$ confluency. Then, the cells were treated with different concentrations of $C x c$ stem extract ranging from 0.02 to $3 \mathrm{mg} / \mathrm{mL}$ for $24 \mathrm{~h}$ and $48 \mathrm{~h}$. The cells on coverslips were fixed for $15 \mathrm{~min}$ in cold methanol at $-20^{\circ} \mathrm{C}$ and then washed three times in PBS and stained with DAPI (Lonza) for 5 min followed by three washings with distilled water. Then the coverslips were mounted on the microscopic slides using mounting medium. The mitotic index was determined as number of mitotic cells out of 1000 cells. Three counts of the cells were performed and the median value was considered.

DNA electrophoresis in agarose gel. $1 \times 10^{6} \mathrm{MCF}-7$ cells were seeded in $100 \mathrm{~mm}$ Petri dishes, let to adhere for $24 \mathrm{~h}$ and treated with different concentrations of $C x c$ stem extract for $24 \mathrm{~h}$ and $48 \mathrm{~h}$. Then the cells were harvested, the pellet was washed with cold PBS and stored at $-20^{\circ} \mathrm{C}$ or immediately processed for DNA isolation (Qiagen kit). Equal volumes of isolated DNA were loaded on $1 \%$ agarose gel (Serva), run in a horizontal agarose electrophoresis system (BioradMinigel) and then the gel was photographed under UV light (Syngene Gel Documentation System).

Statistical analysis. Data are from at least three independent experiments and are expressed as means \pm standard deviation. Data were statistically evaluated using OriginPro 8 software. The significance of the results was determined using Student t-test. The results were considered significant when $\mathrm{p}<0.05$. EC 50 (effective concentration, the concentration of a drug that gives the half maximal response) was calculated as a derived parameter from the non-linear fitting curve using the above mentioned software. 


\section{Results and Discussion}

TLC-Fingerprints of CXc extracts. TLC profile of ethanolic extracts of flower (F), leaves (L) and stems (S) from $C x c$ revealed that the plant parts analysed have similar phytochemical profiles, although THE $\mathrm{S}$ extract seem to be more different as evidenced by more intense bands in certain regions on the chromatogram and lighter bands in other region. TLC plates were developed using vanillin/sulphuric acid system that is likely to detect steroids, higher alcohols, phenols and essential oils and these groups of compounds are suggestive to be present in the studied extracts.

Three solvent systems were used (EMW, CEF and BEA) in order to separate the compounds from the studied extracts. CEF (chloroform:ethyl acetate:formic acid 5:4:1) solvent system, an intermediate polarity system, was the most efficient from all of them as shown by the great number of bands on the chromatogram (Figure 1a). With the polar EMW solvent system (ethyl acetate: methanol: water) the bands were poorly separated and the running was uneven, active zones appearing at very low Rf values (data not shown). In the case of non-polar BEA (benzene:ethyl acetate:ammonia) solvent system, the active zones separated poorly and were very close to the solvent front on the chromatogram indicating that the compounds were relatively more polar (results not shown).

Qualitative detection of phenolic compounds in Cxc extracts. The phenolic constituents were visualized by spraying the TLC plates with ferric chloride.
The presence of dark coloured band indicates the existence of phenolic compounds in the analyzed extracts and a strong reacting band is present in the $\mathrm{S}$ extract of $C x c$. (Figure 1b).

a.

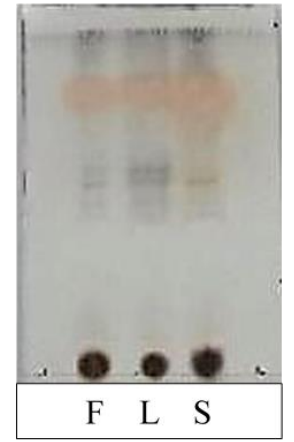

b.

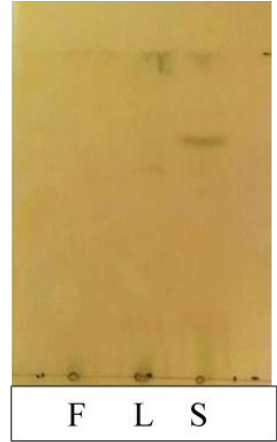

Figure 1.

TLC fingerprints of Caryopteris $x$ clandonensis ethanolic extracts of flowers (F), leaves (L) and stems (S) using CEF solvent system and vanillin/ sulphuric acid (a) or ferric chloride (b) for developing the TLC plates

MTT cytotoxicity test. The ethanolic stem extract of $C x c$ was found to have the highest cytotoxic effect on MCF-7 cell line comparing with other ethanolic extracts obtained from leaves and flowers that were used for TLC profiling (results not shown) and was chosen for further investigation.

The ethanolic stem extract displayed cytotoxic effect on MCF-7 breast cancer cell line when treatment was applied for $24 \mathrm{~h}$ or $48 \mathrm{~h}$ (Figure 2).
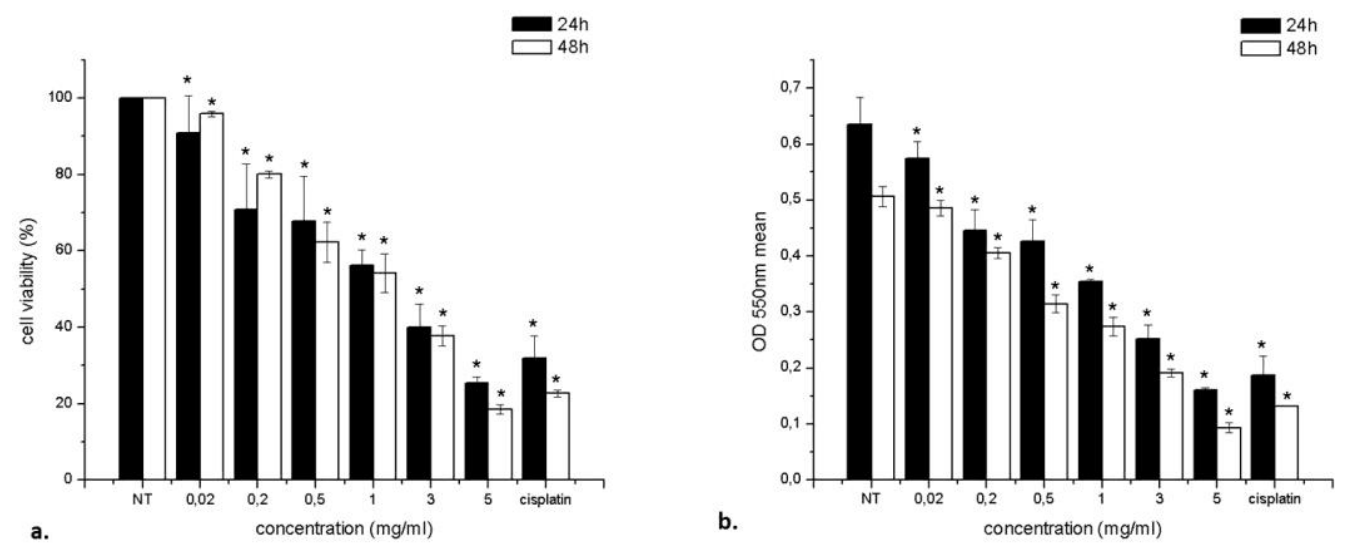

Figure 2.

Inhibition of cell proliferation by Caryopteris X clandonensis extract. (a) Viability of MCF-7 cells treated with Caryopteris X clandonensis extract for 24 and $48 \mathrm{~h}$. (b) Absorbance at $550 \mathrm{~nm}$ means of MCF-7 cells treated with Caryopteris X clandonensis extract for 24 and $48 \mathrm{~h}(* \mathrm{p}<0.05$ versus NTcontrol)

The calculated EC50 was $1.25 \mathrm{mg} / \mathrm{mL}$ when cells were treated for $24 \mathrm{~h}$ and $1.13 \mathrm{mg} / \mathrm{mL}$ when the cells were treated for $48 \mathrm{~h}$. A significant decrease in cell proliferation (with almost 30\% compared with no treated-NT-cells) was observed at a relatively small concentration of the extract $(0.2 \mathrm{mg} / \mathrm{mL})$. It 
can be observed there is a small difference between $24 \mathrm{~h}$ treatment and $48 \mathrm{~h}$ treatment that can be interpreted as the extract treatment has almost the same efficacy at $24 \mathrm{~h}$ as at $48 \mathrm{~h}$. Cisplatin, used as a positive control, inhibited the cell proliferation with almost $70 \%$ for the $24 \mathrm{~h}$ treatment and with $80 \%$ for the $48 \mathrm{~h}$ treatment. The cytotoxic activity of cisplatin $(60 \mathrm{mM})$ was significantly lower when compared to the last tested concentration $(5 \mathrm{mg} / \mathrm{mL})$ of the extract. Although cisplatin is more cytotoxic than the ethanolic extract of $C x c$, given the side effects of chemotherapic drugs, the studied extract can be considered to have a considerable cytotoxic activity. Further studies will be employed to assess the possibility of synergistic effect of $C x c$ ethanolic extract and cisplatin.
DAPI staining. In order to see if the $C x c$ extract has an effect on the morphology of the cell nucleus, MCF-7 cells were treated for $24 \mathrm{~h}$ and $48 \mathrm{~h}$ with different concentrations of the extract. We observed the increase of apoptosis/necrosis with the concentration of the extract. The higher the concentration of the extract, the higher was the degree of apoptosis. The treatment with the smallest extract concentration $0.02 \mathrm{mg} / \mathrm{mL}$ - leads to an increase in the frequency of mitotic cells (Figure 3a). This fact was confirmed by mitotic index analysis (Figure $3 b$ ) that shows an increase in the number of mitotic cells with more than $10 \%$ for the $24 \mathrm{~h}$ treatment and with more than $20 \%$ in the case of $48 \mathrm{~h}$ treatment.
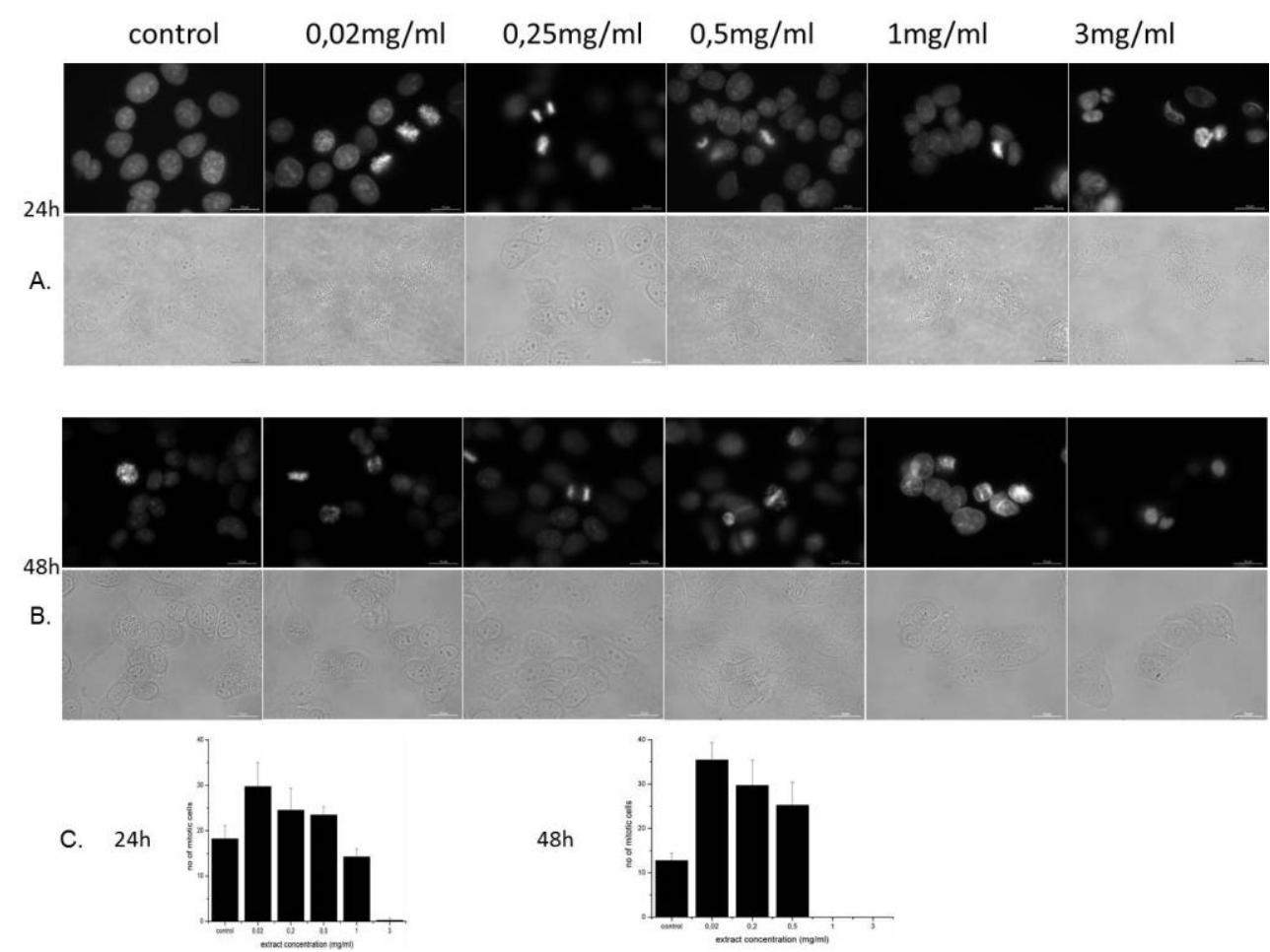

Figure 3.

Images of DAPI nuclear staining and transmitted light of MCF-7 cells treated for $24 \mathrm{~h}$ or $48 \mathrm{~h}$ and not treated with Caryopteris $x$ clandonensis extract. A. $24 \mathrm{~h}$ treatment of MCF-7 cells with the ethanolic extract; more mitotic cells can be observed at $0.02 \mathrm{mg} / \mathrm{mL}$ concentration. B. $48 \mathrm{~h}$ treatment shows an earlier onset of the apoptosis/necrosis.

C. The mitotic index of the cells treated for $24 \mathrm{~h}$ or for $48 \mathrm{~h}$ indicates an increased number in mitotic cells that occurs at $0.02 \mathrm{mg} / \mathrm{mL}$ treatment. Data are expressed as means \pm SD of three independent replicates.

The number of mitotic cells for the other concentrations of the extract treatments $(0.2 \mathrm{mg} / \mathrm{mL}, 0.5 \mathrm{mg} / \mathrm{mL})$ is maintained higher than in the control but the difference between control and the treated cells is higher for the $48 \mathrm{~h}$ treatment than for the $24 \mathrm{~h}$, due to a longer contact of the cells with the treatment applied. The higher number of mitotic cells suggests that cells are blocked in mitosis and cannot exit this phase of the cell cycle. In the case of $24 \mathrm{~h}$ treatment, the number of mitotic cells was smaller for the treatment with $1 \mathrm{mg} / \mathrm{mL}$ concentration of extract than in the control slide and almost zero for the treatment with highest concentration $(3 \mathrm{mg} / \mathrm{mL})$. In the case of $48 \mathrm{~h}$ treatment, the decrease in the number of mitotic cells was dramatic for the $1 \mathrm{mg} / \mathrm{mL}$ and $3 \mathrm{mg} / \mathrm{mL}$ concentration of the extract. This decrease in the number of mitotic cells is due to the fact that cells massively entered apoptosis/necrosis. This extensive phenomenon of apoptosis can be interpreted as an activation of the cell cycle checkpoint that causes the cells blocked in mitosis to enter apoptosis and later on necrosis. 
DNA fragmentation assay. To evaluate the integrity of DNA from cells that underwent treatment with various concentrations with $C x c$ extract, DNA analysis was performed. It was observed that the treatment of the cells with the extract had a significant effect on the MCF-7 cells. The increase in the concentration of the extract leads to degradation of the DNA. In the control sample the DNA was intact, not degraded for $24 \mathrm{~h}$ and $48 \mathrm{~h}$ treatment. As the concentration of the treatment increases, the bands are less intense (Figure $4 \mathrm{a}$ ) in the case of $24 \mathrm{~h}$ treatment, till complete disappearance for the highest concentration of the $48 \mathrm{~h}$ treatment (Figure $4 \mathrm{~b}$ ).
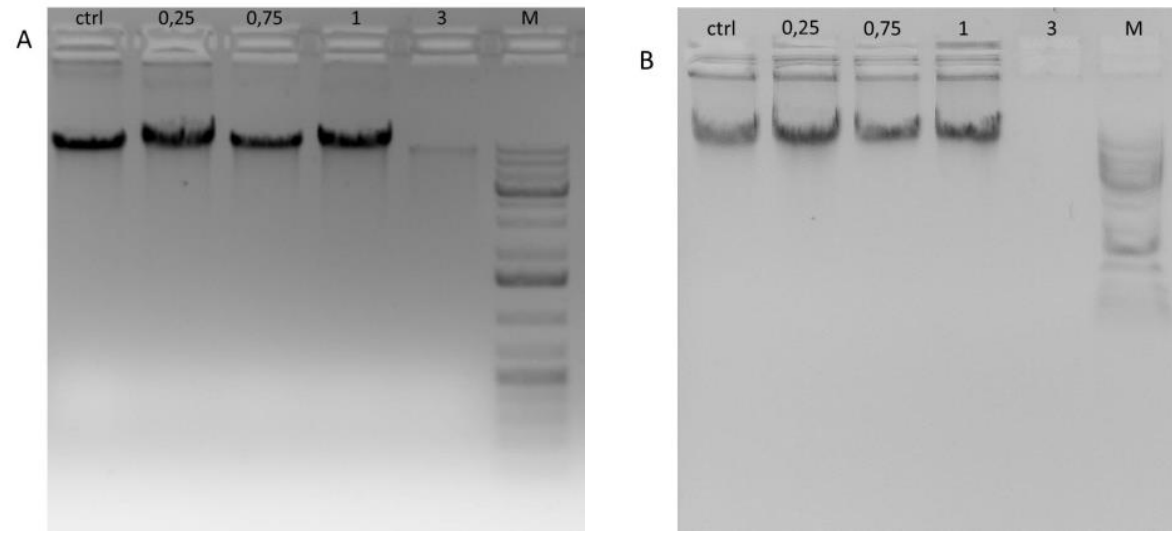

Figure 4.

DNA integrity upon treatment with Caryopteris $x$ clandonensis extract. From left to right, each well was loaded with DNA isolated from non-treated cells (ctrl), from cells treated with $0.25 \mathrm{mg} / \mathrm{mL}, 0.75 \mathrm{mg} / \mathrm{mL}, 1 \mathrm{mg} / \mathrm{mL}$ and $3 \mathrm{mg} / \mathrm{mL}$ extract. The last well corresponds to the molecular weight marker (M).

A - treatment for $24 \mathrm{~h}$ and B - treatment for $48 \mathrm{~h}$

Though, in this assay it was not observed a degradation pattern as a leader that is specific for apoptosis as it was described in other studies but this does not exclude the apoptosis as a DNA degradation mechanism [21]. However, the underlying mechanism of action of the Cxc extract on the DNA of MCF-7 cells was not investigated.

\section{Conclusions}

This study investigates for the first time the Caryopteris $x$ clandonesis hybrid as a medicinal plant and demonstrates its potential antiproliferative effect on breast cancer cells. The current results show the treated cells with stem extracts display an increased mitotic index and the high degree of apoptosis/necrosis proportional with the concentration of the extract. Further studies that assess the biological potential of certain isolated compounds will be taken into account but this research suggests the potential of $C x c$ stem extract as a natural antiproliferative agent.

\section{References}

1. Ferlay J, Soerjomataram I, Dikshit R, Eser S, Mathers C, Rebelo M, Parkin DM, David Forman D, Bray F, Cancer incidence and mortality worldwide: Sources, methods and major patterns in GLOBOCAN 2012. Int J Cancer, 2015; 136: E359-E386.

2. Hanahan D, Weinberg RA, Hallmarks of cancer: The next generation. Cell, 2011; 144(5): 646-674.
3. Salmela AL, Kallio MJ, Mitosis as an anti-cancer drug target. Chromosoma, 2013; 122: 431-449.

4. McKenzie SD, Perenial Ground covers, Timber Press Inc., Portland, 97204 Oregon, USA, 2003.

5. Huxley AJ, Griffiths M, Levy M, Royal Horticultural Society, New RHS Dictionary of Gardening, Macmillan Press, London, UK, 1992.

6. www. missouribotanicalgarden.org

7. Hannedouche S, Souchard JP, Jacquemond-Collet I, Moulis C, Molluscicidal and radical scavenging activity of quinones from the root bark of Caryopteris $x$ clandonensis. Fitoterapia, 2002; 73: 520-522.

8. Hannedouche S, Stanislas E, Moulis C, Fouraste I, Iridoids from Caryopteris x clandonensis. Phytochemistry, 2000; 54: 807-809.

9. Murata T, Selenge E, Oikawa S, Ageishi K, Batkhuu J, Sasaki K, Yoshizaki F, Colinesterase-inhibitory diterpenoids and chemical constituents from aerial parts of Caryopteris mongolica. J Nat Med., 2015; 69(4): 471-478.

10. Batkhuu J, Sanchir C, Ligaa U, Jamsran T, Colored ilustrations of Mongolian useful plants, vol. 2, Admon Print, Ulaanbaatar, Mongolia, 2005.

11. Xiao PG, Mayanagi M, A pictorial encyclopedia of Chinese medical herbs, vol. 5, Japanese edition, Chuokoronsha, Tokio, Japan, 1993.

12. Saruul E, Murata T, Selenge E, Sasaki K, Yoshizaki F, Batkhuu J, An antibacterial ortho-quinone diterpenoid and its derivatives from Caryopteris mongolica. Bioorg Med Chem Lett., 2015; 25(12): 2555-2558.

13. Murata T, Ishikawa Y, Saruul E, Selenge E, Sasaki K, Umehara K, Yoshizaki F, Batkhuu J, Abietanetype diterpenoids from the roots of Caryopteris 
mongolica and their cholinesterase inhibitory activities. Phytochemistry, 2016; 130: 152-158.

14. Ahn DK, Illustrated Book of Korean Medicinal Herbs, Kyohak Publishing Co., Seoul, Koreea, 1998.

15. Park S, Son MJ, Yook CS, Jin C, Lee YS, Kim HJ, Chemical constituents from aerial parts of Caryopteris incana and cytoprotective effects in human HepG2 cells. Phytochemistry, 2014; 101: 83-90.

16. Gao JJ, Igalashi K, Nukina M, Radical scavenging activity of phenylpropanoid glycosides in Caryopteris incana. Bioscience Biotechnology Biochemistry, 1999; 63(6): 983-988.

17. Gao J, Igarashi K, Nukina M, Three new phenylethanoid glycosides from Caryopteris incana and their antioxidative activity. Chem Pharmaceut Bull. (Tokyo), 2000; 48(7): 1075-1078.
18. Yoshikawa K, Harada A, Iseki K, Hashimoto T, Constituents of Caryopteris incana and their antibacterial activity. $J$ Nat Med., 2014; 68(1): 231-235.

19. Seo EJ, Kuete V, Kadioglu O, Krusche B, Schröder S, Greten HJ, Arend J, Lee IS, Efferth T, Antiangiogenic activity and pharmacogenomics of medicinal plants from traditional Korean medicine. Evid Based Compl Alt Med., 2013; 2013: 1-13.

20. Zhao SM, Chou GX, Yang QS, Wang W, Zhou JL, Abietane diterpenoids from Caryopteris incana (Thunb.) Miq. Org Biomol Chem., 2016; 14(14): 3510-3520.

21. Tanih NF, Ndip RN, The acetone extract of Sclerocarya birrea (Anacardiaceae) possesses antiproliferative and apoptotic potential against human breast cancer cell lines (MCF-7). Sci World J., 2013; 2013: 1-7. 